\title{
MANAJEMEN MODAL KERJA, KENDALA KEUANGAN, DAN PROFITABILITAS PADA PERUSAHAAN MANUFAKTUR INDONESIA
}

\author{
Lukas Purwoto \\ luk@usd.ac.id \\ Fakultas Ekonomi Universitas Sanata Dharma Yogyakarta
}

\begin{abstract}
One of the main concerns of corporate financial management is how managers make short-term decisions known as working capital management. This requires managers' decisions in working capital policy and management that have an impact on performance. This study aims to investigate the importance of working capital management for the profitability of Indonesian manufacturing public companies in the current time periods. The results of the analysis using panel data regressions show a concave-shaped relationship between working capital management (NTC) and profitability (both ROE and NPM). The results of this study suggest that an increase in working capital will increase profitability when the level of working capital is low, but profitability will be decreased along with an increase in working capital when the level of working capital is high. These results indicate that the companies have an optimal level of working capital that maximizes profitability. This study also proposes an estimate for the optimal level of NTC for the company. Subsequent investigations is carried out by examining the effect of financial constraints on optimal working capital levels. The test results show that financial constraints affect the relationship between working capital management and profitability.
\end{abstract}

Key words: working capital management; financial constraints; profitability.

\begin{abstract}
ABSTRAK
Salah satu perhatian utama dari manajemen keuangan perusahaan ialah pada bagaimana manajer membuat keputusan keuangan jangka pendek yang dikenal sebagai manajemen modal kerja. Hal ini menuntut keputusan manajer dalam kebijakan dan pengelolaan modal kerja yang berdampak pada kinerja. Penelitian ini bertujuan untuk menginvestigasi pentingnya manajemen modal kerja bagi profitabilitas perusahaan manufaktur terbuka Indonesia pada periode waktu terkini. Hasil-hasil analisis dengan menggunakan regresi data panel menunjukkan adanya hubungan kuadratik yang berbentuk U terbalik antara manajemen modal kerja (NTC) dan profitabilitas (keduanya ROE dan NPM). Hasil-hasil penelitian ini menyarankan bahwa peningkatan modal kerja akan meningkatkan profitabilitas ketika tingkat modal kerja adalah rendah, namun profitabilitas akan menjadi turun seiring dengan peningkatan modal kerja ketika tingkat modal kerja adalah tinggi. Hasil-hasil ini mengindikasikan bahwa perusahaan mempunyai tingkat modal kerja optimal yang memaksimalkan profitabilitas. Penelitian ini juga mengajukan suatu taksiran yang bagus untuk tingkat NTC yang optimal bagi perusahaan. Penyelidikan selanjutnya dilakukan dengan menguji pengaruh dari kendala keuangan terhadap tingkat modal kerja optimal. Hasil-hasil pengujian menunjukkan bahwa kendala keuangan berpengaruh pada hubungan antara manajemen modal kerja dan profitabilitas.
\end{abstract}

Kata kunci: manajemen modal kerja, kendala keuangan, profitabilitas

\section{PENDAHULUAN}

Satu topik utama yang dibahas dalam manajemen keuangan perusahaan ialah bagaimana manajer membuat keputusan jangka pendek atau yang dikenal sebagai manajemen modal kerja. Manajemen modal kerja merupakan satu bahasan yang penting mengingat kelangsungan hidup perusahaan tergantung kepada kemampuan manajer untuk secara efektif mengelola piutang 
usaha, persediaan, dan hutang usaha (Gitman dan Zutter, 2012). Terkait dengan hal ini, persentase besarnya rupiah pada aset lancar dan kewajiban lancar kiranya dapat mencerminkan pentingnya item-item tersebut pada laporan posisi finansial atau neraca perusahaan. Data yang diambil dari sampel penelitian ini memperlihatkan bahwa nilai rata-rata aset lancar terhadap total aset adalah sekitar 52 persen pada perusahaan terbuka manufaktur di Bursa Efek Indonesia. Selain itu, nilai rata-rata kewajiban lancar terhadap total aset adalah sekitar 36 persen. Untuk itu, pengelolaan modal kerja yang baik merupakan kegiatan harian yang penting untuk diperhatikan oleh para manajer guna memastikan bahwa sumber daya perusahaan telah mencukupi bagi kelangsungan usaha bisnis secara efektif.

Pada beberapa tahun terakhir ini, manajemen modal kerja mendapat perhatian yang semakin meningkat dari perusahaan maupun dari pihak-pihak lain yang berhubungan dengan pasar modal khususnya dalam kegiatan pendanaan kebutuhan modal kerja. Dalam suatu berita bisnis CNN Indonesia (2017), Otoritas Jasa Keuangan (OJK) menyampaikan bahwa selama periode Januari sampai dengan Maret 2017, sebanyak 23 perusahaan emiten memperoleh dana di pasar modal sebanyak Rp33,2 triliun, yang meningkat 40,1 persen dibandingkan dengan periode yang sama di tahun 2016. Pada berita CNN tersebut, OJK menjelaskan bahwa berbeda dari tahun sebelumnya, pada tahun 2017 direncanakan sebanyak 24 persen dana digunakan untuk ekspansi usaha dan 69 persen untuk modal kerja.

Namun, survei modal kerja perusahaan yang dilakukan oleh konsultan PwC (2015) menyampaikan temuan bahwa perusahaanperusahaan Asia tertinggal dari kebanyakan wilayah US atau Kanada dan Eropa dalam hal kinerja manajemen modal kerja dan bahkan kesenjangan tersebut membesar. Survei PwC ini menekankan perlunya perhatian manajer perusahaan terhadap kebija- kan dan pengelolaan modal kerja, yang seolah-olah mengalirnya darah kehidupan perusahaan yang berdampak besar pada kinerja.

Seiring dengan dinamika manajemen bisnis, penelitian dalam topik manajemen modal kerja perusahaan semakin populer akhir-akhir ini dilakukan oleh para peneliti. Sejumlah penelitian menunjukkan bahwa modal kerja signifikan berpengaruh negatif terhadap profitabilitas (Yazdanfar dan Ohman, 2014; Pais dan Gama, 2015). Namun, beberapa peneliti terdahulu yang lainnya malah menemukan pengaruh yang positif dari manajemen modal kerja terhadap profitabilitas perusahaan (Zakari dan Saidu, 2016; Veli, 2015). Menariknya lagi, beberapa penelitian di Indonesia memperlihatkan pengaruh yang tidak signifikan dari manajemen modal kerja terhadap profitabilitas. Meidiyustiani (2016) menyampaikan temuan bahwa modal kerja tidaksignifikan berpengaruh terhadap profitabilitas perusahaan di sektor industri barang konsumsi. Sedangkan, Reimeinda et al. (2016) juga menemukan tidak adanya pengaruh yang signifikan dari modal kerja terhadap profitabilitas pada perusahaan sektor telekomunikasi. Temuan-temuan yang kurang konsisten bahkan berlawanan ini menjadi semakin menarik untuk diteliti lebih lanjut pada penelitian sekarang ini.

Melihat peran pentingnya manajemen modal kerja, suatu perusahaan bisa saja memilih kebijakan manajemen modal kerja secara konservatif ataukah secara agresif (Baños-Caballero et al., 2012; Afrifa dan Padachi, 2016; Afrifa, 2016; Altaf dan Shah, 2018). Kebijakan konservatif mengarahkan kepada investasi tinggi dari modal kerja yang berkonsekwensi pada risiko rendah dan return rendah. Sebaliknya, kebijakan agresif mengarahkan pada investasi rendah dari modal kerja yang berkonsekwensi pada risiko tinggi dan return tinggi. Penelitian sekarang ini mempertimbangkan keduanya baik strategi konservatif maupun strategi agresif dari manajemen modal kerja. Pertimbangan hal ini dikarenakan bahwa 
keputusan modal kerja menjadi komplit dan berwawasan luas apabila dapat dipahami dalam berbagai alternatif kebijakan yang tersedia pada manajer perusahaan.

Dua pertanyaan riset berikut diajukan pada penelitian ini. Pertama adalah apakah asosiasi antara manajemen modal kerja dan profitabilitas pada perusahaan terbuka manufaktur Indonesia dapat dinyatakan dalam satu pola hubungan kuadratik? Kedua adalah apakah hubungan antara manajemen modal kerja dan profitabilitas dipengaruhi oleh faktor kendala keuangan perusahaan?

Tujuan penelitian ini adalah untuk menginvestigasi pentingnya manajemen modal kerja bagi profitabilitas dari pe usahaan terbuka manufaktur Indonesia pada periode waktu terkini. Penelitian ini memberikan empat kontribusi bagi literatur. Pertama adalah masih sangat jarangnya penelitian yang menguji hubungan non linier antara manajemen modal kerja dan profitabilitas perusahaan Indonesia. Kedua, penelitian ini merupakan yang pertama (sepengetahuan penulis saat ini) dalam menguji pengaruh kendala keuangan pada hubungan non linier antara manajemen modal kerja dan profitabilitas pada perusahaan Indonesia. Ketiga, riset ini menggunakan ukuran manajemen modal kerja, yaitu net trade cycle (NTC), yang cukup jarang ditemukan dalam literatur riset keuangan di Indonesia. Dan keempat, penelitian ini menerapkan analisis regresi pada data panel secara cukup lengkap.

Dewi dan Rahayu (2016) serta Utami dan Dewi S (2016) telah meneliti pengaruh manajemen modal kerja terhadap profitabilitas pada perusahaan terbuka manufaktur Indonesia. Akan tetapi perhatian kedua penelitian tersebut lebih pada masing-masing komponen dari modal kerja, dan terlebih lagi dalam suatu pola hubungan liniear seperti pada umumnya penelitian lain. Demikian juga, penelitian Wiyono (2017) menguji dalam hubungan liner pada pengaruh siklus konversi kas terhadap price earning ratio pada perusahaan sektor aneka usaha di BEI selama periode 2012-2015. Ketiga penelitian dahulu tersebut berbeda dengan penelitian sekarang ini dalam sejumlah hal, seperti: hipotesis yang diajukan, variabel, periode waktu, dan cara analisis penelitian.

Belum lama ini, Singhania dan Mehta (2017) mempertunjukkan hubungan non linier antara manajemen modal kerja dan profitabilitas perusahaan non keuangan dari sejumlah negara-negara Asia termasuk Indonesia. Penelitian mereka menggunakan cash conversion cycle (CCC) sebagai ukuran manajemen modal kerja dan return on assets (ROA) untuk pengukur profitabilitas. Selain berbeda dalam hal penerapan metode estimasi data panel dan periode waktu analisisnya, penelitian sekarang ini menggunakan net trade cycle (NTC) sebagai ukuran manajemen modal kerja, serta return on equity (ROE) dan net profit margin (NPM) sebagai ukuran profitabilitas perusahaan. Untuk itu, hasil penelitian sekarang ini diharapkan dapat memperkaya literatur manajemen modal kerja di Indonesia.

\section{TINJAUAN TEORETIS}

Manajemen keuangan perusahaan tentu saja tidak hanya menaruh perhatian pada pertanyaan-pertanyaan mengenai persoalan penganggaran modal maupun keputusan pendanaan jangka panjang. Manajemen keuangan juga menaruh perhatian pada bagaimana perusahaan mengelola kegiatan hariannya yang berhubungan dengan keputusan keuangan jangka pendek. Topik pembahasan seperti ini dikenal sebagai manajemen modal kerja, yang menunjuk pada perhatian manajer pada hal-hal yang terkait dengan aktiva lancar seperti piutang usaha dan persediaan serta terkait dengan kewajiban lancar seperti hutang usaha kepada pemasok.

Ross et al. (2013) menegaskan bahwa mengelola modal kerja merupakan kegiatan sehari-hari manajer yang berguna dalam memastikan bahwa perusahaan mempunyai sumber daya yang mencukupi untuk melangsungkan kegiatan usahanya serta 
menghindarkan diri dari interupsi yang berbiaya. Oleh karenanya, perusahaan perlu mengelola modal kerjanya dengan baik agar kinerja perusahaan yang tinggi dapat terpelihara. Karena banyak perusahaan mempunyai variasi tinggi sehubungan dengan kemampuan dalam pengelolaan modal kerjanya, maka diperlukan suatu ukuran efektivitas yang bisa berlaku secara menyeluruh antar perusahaan.

Dalam buku yang khusus membahas manajemen modal kerja, Preve dan SarriaAllende (2010) menguraikan adanya siklus yang umum dijumpai pada kegiatan usaha yang berhubungan dengan pengelolaan modal kerja. Perusahaan non keuangan umumnya mengawali siklus usahanya dengan melakukan pembelian bahan baku secara kredit sehingga memunculkan hutang usaha. Periode hutang usaha ialah lamanya waktu antara pembelian kredit dan pembayaran kas. Perusahaan kemudian menggunakan bahan baku tersebut untuk diproses menjadi barang akhir yang dapat dijual. Periode lamanya antara waktu pembelian awal dalam persediaan sampai dengan waktu penjualan disebut sebagai periode persediaan. Selanjutnya perusahaan menjual produk akhir secara kredit sehingga memunculkan piutang usaha. Perbedaan lamanya antara penerimaan kas dari konsumen dan penjualan kredit disebut sebagai periode piutang usaha. Dalam siklus ini, ada titik waktunya antara perusahaan harus mengeluarkan kas dan kemudian memperoleh kas, yang karenanya terkait dengan investasi dana.

Satu metode yang semakin populer guna mengevaluasi efisiensi manajemen modal kerja perusahaan ialah dengan usaha untuk meminimalkan tingkatan modal kerja. Semakin meningkatnya persaingan antar perusahaan dan meningkatnya perhatian manajemen mengarahkan pada rasionalisasi investasi jangka pendek sehingga menyebabkan manajemen modal kerja menjadi krusial bagi profitabilitas (Yazdanfar dan Ohman, 2014). Usaha meminimalkan modal kerja perusahaan dapat dilakukan dengan sejumlah cara, seperti: mempercepat penagihan kas, meningkatkan perputaran persediaan, dan memperlambat pembayaran kas. Oleh karenanya, pandangan efisiensi akan mengikuti kebijakan agresif, yang menyarankan bahwa profitabilitas dapat ditingkatkan dengan menurunkan investasi dalam modal kerja (Pais dan Gama, 2015).

Pandangan efisiensi modal kerja tersebut telah mengarahkan banyak peneliti menganalisis hubungan linier yang negatif antara manajemen modal kerja dan profitabilitas perusahaan. Lebih dari satu dekade yang lalu, Deloof (2003) telah menunjukkan hubungan negatif antara manajemen modal kerja dan profitabilitas pada perusahaan besar Belgia. Temuantemuan sejenis dalam hubungan negatif juga masih ditunjukkan oleh sejumlah penelitian terkini, seperti: Nobanee et al. (2011) pada perusahaan Jepang, Yazdanfar dan Ohman (2014) pada perusahaan Swedia, serta Pais dan Gama (2015) pada perusahaan Portugis. Belum lama ini, penelitian Lyngstadaas dan Berg (2016) mempertunjukkan hasil empiris bahwa penurunan cash conversion cycle (CCC) akan meningkatkan profitabilitas perusahaan di Norwegia. Dengan demikian, dukungan atas praktek kebijakan modal kerja yang agresif dikonfirmasi oleh hasil sejumlah penelitian terdahulu tersebut.

Namun, pandangan yang berkebalikan diajukan oleh sejumlah peneliti dengan menyarankan modal kerja sebagai pendorong penjualan yang akhirnya meningkatkan profitabilitas perusahaan (Deloof, 2003). Belum lama ini, Zakari dan Saidu (2016) menunjukkan pengaruh yang positif dari manajemen modal kerja, yang diukur dengan CCC, terhadap profitabilitas perusahaan yang terdaftar di Pasar Saham Nigeria. Dengan menggunakan data perusahaan kecil dan menengah di Turkey, analisis Veli (2015) menemukan hubungan positif antara manajemen modal kerja dan profitabilitas. Dengan demikian, pandangan ini menyepakati kebijakan konservatif, yang 
menyarankan perlunya menjaga tinggi tingkatan investasi dalam modal kerja.

Baños-Caballero et al. (2012) memulai yang pertama dalam mengambil posisi yang mengakomodasi kedua kebijakan tersebut baik agresif maupun konservatif untuk berlaku pada perusahaan. Studi mereka menunjukkan adanya hubungan non linier yang kuadratik antara manajemen modal kerja dan profitabilitas perusahaan di Spanyol. Penelitian Afrifa dan Padachi (2016) mengambil sampel perusahaan kecil dan menengah yang terdaftar di pasar saham Inggris. Analisis regresi data panel mereka menunjukkan hubungan cekung antara tingkatan modal kerja (CCC) dan profitabilitas perusahaan. Hasil studi ini menyarankan perlunya perusahaan untuk mencapai tingkat yang optimal dari modal kerja sehingga akan memaksimumkan profitabilitas. Belum lama ini, studi empiris Altaf dan Shah (2018) juga mengkonfirmasi keberadaan hubungan berbentuk $U$ terbalik antara manajemen modal kerja dan profitabilitas perusahaan pada perusahaan non keuangan India. Akan tetapi bentuk hubungan U terbalik tidak didukung oleh penelitian Pais dan Gama (2015) pada perusahaan Portugis.

Dengan demikian, strategi konservatif dari manajemen modal kerja perusahaan ditunjukkan oleh lebih tingginya investasi dalam modal kerja, yang dalam hal ini mencerminkan lebih banyaknya kredit dagang kepada konsumen, lebih tingginya tingkatan persediaan, dan semakin sedikitnya pendanaan dari pemasok. Akan tetapi sebaliknya, strategi agresif dari kebijakan modal kerja menunjukkan lebih rendahnya kredit dagang pada konsumen, lebih rendahnya persediaan, dan semakin menunda pembayaran kas pada pemasok. Ringkasnya, kedua strategi tersebut mempunyai pendapat atau argumentasi preferensinya seperti yang dirangkum pada Tabel 1.

Tabel 1

Strategi Konservatif versus Strategi Agresif

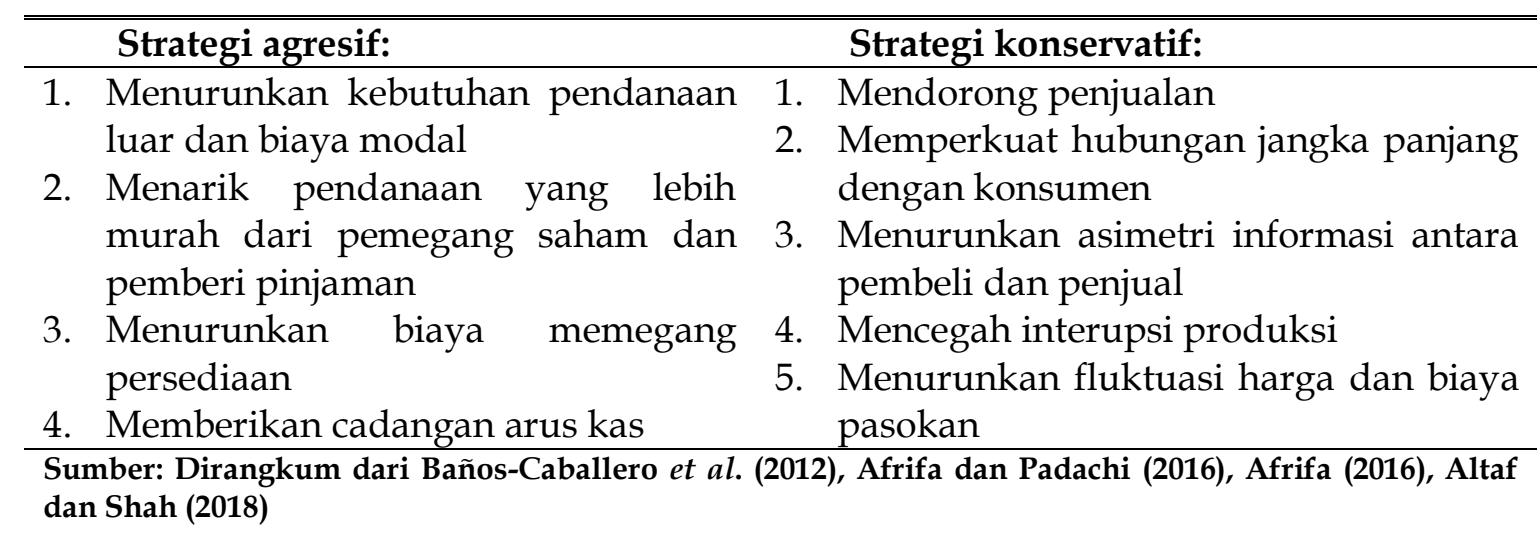

Seperti yang telah didiskusikan pada bagian ini sebelumnya, keputusan dalam manajemen modal kerja perusahaan mengandung adanya suatu trade-off, oleh karenanya perusahaan akan mengusahakan untuk menjaga suatu tingkatan yang optimal dari investasi modal kerja sehingga akan menyeimbangkan keduanya baik manfaat dan biaya yang memaksimalkan profitabilitas perusahaan (Baños-Caballero et al., 2012; Afrifa dan Padachi, 2016; Altaf dan Shah, 2018). Pada situasi tingkat rendah dari modal kerja, profitabilitas perusahaan seharusnya meningkat seiring dengan meningkatnya modal kerja. Namun pada situasi tingkat tinggi dari modal kerja, profitabilitas akan menjadi turun dengan meningkatnya modal kerja. Hal ini mengarahkan pada penelitian ini untuk mengharapkan bahwa hubungan antara modal 
kerja dan profitabilitas akan positif pada tingkatan rendah dari modal kerja, namun negatif pada tingkatan yang lebih tinggi. Dengan demikian, hubungan antara manajemen modal kerja dan profitabilitas bisa jadi berbentuk cekung (concave). Dengan kata lain, perusahaan mempunyai tingkat modal kerja optimal yang karenanya memaksimalkan profitabilitas.

Uraian tersebut mengarahkan pada pernyataan hipotesis penelitian yang pertama sebagai berikut:

$\mathrm{H}_{1}$ : Pengaruh manajemen modal kerja terhadap profitabilitas perusahaan manufaktur Indonesia bisa dinyatakan dalam hubungan kuadratik berbentuk cekung.

Perhatian penelitian sekarang ini juga diarahkan pada masuknya faktor kondisi kendala keuangan (financial constraints) dalam kaitannya dengan manajemen modal kerja perusahaan. Terkait dengan hal ini, pentingnya pendanaan bagi dinamika perkembangan perusahaan telah cukup lama dicatat dalam literatur. Studi Li (2011) memfokuskan kepada situasi dimana penelitian dan pengembangan ( $R$ \& $D)$ perusahaan menghadapi kendala keuangan yang menghambat kemampuan perusahaan untuk mendanai proyek-proyek baru maupun yang sedang berjalan. Fazzari dan Petersen (1993) telah menyarankan bahwa dibandingkan dengan investasi dalam modal tetap, investasi dalam modal kerja lebih sensitif terhadap kendala keuangan. Terkait dengan hal tersebut, Wasiuzzaman (2015) menunjukkan bahwa perbaikan dalam efisiensi modal kerja menghasilkan nilai perusahaan yang lebih tinggi hanya terjadi pada perusahaan yang terkendala keuangan, namun tidak pada perusahaan yang tidak terkendala keuangan.

Baños-Caballero et al. (2014) lalu melanjutkan pengujian hubungan antara manajemen modal kerja dan profitabilitas pada perusahaan terbuka Inggris dengan memasukkan pengaruh kendala keuangan. Mereka mengemukakan bahwa karena tingkat modal kerja yang lebih tinggi membutuhkan pendanaan, yang berarti lebih banyak tambahan biaya, maka perusahaan yang lebih banyak menghadapi kendala keuangan diharapkan mempunyai tingkat modal kerja optimal yang lebih rendah daripada yang kurang mempunyai kendala keuangan. Penelitian Afrifa (2016) mengkonfirmasinya dengan menunjukkan hasil hubungan concave antara modal kerja dan kinerja perusahaan pada tiadanya arus kas, tetapi berganti setelah memasukkan arus kas perusahaan pada hubungan tersebut. Dengan kata lain, diskusi ini mengarahkan bahwa hubungan antara manajemen modal kerja dan profitabilitas seharusnya juga dipengaruhi oleh faktor kendala keuangan perusahaan.

Diskusi tersebut dapat dinyatakan dalam hipotesis penelitian kedua sebagai berikut:

$\mathrm{H}_{2}$ : Kendala keuangan perusahaan mempengaruhi hubungan kuadratik antara manajemen modal kerja dan profitabilitas.

\section{METODE PENELITIAN}

Studi-studi terdahulu menyarankan bahwa ukuran-ukuran manajemen modal kerja perusahaan adalah berbeda signifikan antar industri (Lyngstadaas dan Berg, 2016), dan bahwa manajemen modal kerja mempengaruhi kinerja secara berbeda pada perusahaan di industri yang berbeda (Afrifa, 2016). Untuk mengantisipasi isu spesifik industri, maka perusahaan yang menjadi sampel pada penelitian ini adalah perusahaan non keuangan dalam industri manufaktur, yang mencakup usaha dasar, macam-macam produsen, dan pembuat barang konsumen. Pengambilan sampel perusahaan terbuka manufaktur juga sering dijumpai pada penelitian terdahulu di Indonesia (Dewi dan Rahayu, 2016; Utami dan Dewi S, 2016; Wiyono, 2017).

Data yang digunakan dalam penelitian ini berasal dari laporan keuangan perusahaan terbuka yang terdaftar di Bursa 
Efek Indonesia. Laporan keuangan perusahaan yang diteliti adalah pada periode waktu selama dua tahun dan pada data terkini yang bisa diperoleh, yaitu tahun 2016 dan 2017. Dengan cara demikian, penelitian ini menggunakan data panel yang berisi data lintas waktu dan lintas perusahaan.

Penelitian ini menggunakan dua ukuran yang populer dari profitabilitas perusahaan, yaitu return on equity (ROE) dan net profit margin (NPM). Beberapa penelitian terdahulu pada topik manajemen modal kerja telah menggunakan ROE (misalnya Afrifa dan Padachi, 2016) atau profit margin (misalnya Altaf dan Shah, 2018) sebagai pengukur profitabilitas perusahaan. ROE merupakan ukuran yang populer dari pandangan pemegang saham. Gitman dan Zutter (2012) menjelaskan bahwa ROE mengukur imbal hasil yang diperoleh para pemegang saham biasa atas investasi pada perusahaan. Pada umumnya, pemilik perusahaan menjadi lebih baik ketika rasio ROE ini semakin tinggi. Sementara itu, NPM menghubungkan laba dengan penjualan perusahaan selama satu periode. NPM mengukur persentase rupiah penjualan setelah dikurangi dengan seluruh biaya dan beban (Gitman dan Zutter, 2012). Semakin tinggi ukuran NPM ini, maka posisi profitabilitas perusahaan menjadi semakin baik.

Variabel dependen ROE dan NPM dinyatakan sebagai berikut:

Return on equity (ROE):

$\mathrm{ROE}=$ Laba sesudah pajak atau Total ekuitas

Net profit margin (NPM):

$\mathrm{NPM}=$ Laba sesudah pajak atau Penjualan bersih

Variabel independen ialah manajemen modal kerja perusahaan. Ukuran yang populer dari manajemen modal kerja adalah cash conversion cycle (CCC) pada sejumlah studi terdahulu (Nobanee et al., 2011; Yazdanfar dan Ohman, 2014; Zakari dan Saidu, 2016; Singhania dan Mehta, 2017). Sementara penelitian ini menyelidiki mana- jemen modal kerja perusahaan Indonesia yang diproksi dengan net trade cycle (NTC). Ketika mengawali penggunaan NTC, Shin dan Soenen (1998) berargumen bahwa ukuran CCC sebenarnya merupakan suatu konsep penambahan, yang sayangnya menjadi tidak berlaku sama untuk masingmasing komponennya (yaitu: periode piutang usaha, persediaan, dan hutang usaha) karena item-item pembaginya tidak sama jenis. Mereka meyakini bahwa NTC pada dasarnya sama seperti CCC, yang pada NTC seluruh tiga komponen diekspresikan sama sebagai persentase penjualan. Oleh karena itu, NTC mengindikasikan rata-rata banyaknya hari yang diperlukan oleh perusahaan guna mendanai modal kerja.

Variabel independen NTC dihitung sebagai berikut:

Net trade cycle (NTC):

NTC $=$ (Piutang usaha + Persediaan Hutang usaha) × 365 atau Penjualan bersih

Dalam penelitian ini, lima variabel digunakan sebagai variabel kontrol. Pemilihan variabel kontrol dilakukan dengan mengikuti pada umumnya yang digunakan dalam penelitian terdahulu (Yazdanfar dan Ohman, 2014; Pais dan Gama, 2015; Afrifa, 2016; Altaf dan Shah, 2018). Kelima variabel kontrol yang digunakan pada penelitian ini adalah sebagai berikut:

Ukuran perusahaan (SIZE):

SIZE = logaritma natural dari total asset Leverage (LEV):

LEV $=$ Total kewajiban atau Total asset Current ratio (CR):

$\mathrm{CR}=$ Total aset lancar atau Total kewajiban lancar

Asset tangibility (AT):

$\mathrm{AT}=$ Aset tetap bersih atau Total aset

Usia perusahaan (AGE):

AGE = lamanya tahun perusahaan berdiri

Penelitian ini juga bermaksud untuk menguji pengaruh kendala keuangan (financial constraints) dalam hubungan antara manajemen modal kerja dan profitabilitas. Meski pengukuran kendala keuangan masih menjadi tantangan yang belum terselesai- 
kan (Kirui dan Wawire, 2018), namun penggunaan suatu proksi telah diajukan oleh para peneliti terdahulu. Penelitian ini mengikuti Baños-Caballero et al. (2014) dan Afrifa (2016) dalam mengidentifikasi situasi kendala keuangan melalui arus kas perusahaan. Jelasnya, perusahaan dengan arus kas melebihi (di bawah) median sampel diasumsikan dalam kondisi yang kurang (lebih) menghadapi kendala keuangan. Hasilnya ialah satu variabel dummy untuk kendala keuangan diciptakan. Jadi, proksi berikut diterapkan bagi keberadaan kendala keuangan:

Kendala keuangan (DCF):

$$
\mathrm{DCF}=\left\{\begin{array}{l}
=0, \mathrm{jika} \text { arus kas }>\text { median } \\
=1, \mathrm{jika} \text { arus kas }<\text { median }
\end{array}\right.
$$

Dengan menggunakan data penelitian yang diperoleh, analisis dilakukan dengan menerapkan pendekatan statistika yang tepat, dan difasilitasi dengan menerapkan program komputer Stata 13.0 (Adkins dan Hill, 2011). Pada awalnya, analisis statistika deskriptif dilakukan guna mendapatkan gambaran umum dari variabel penelitian. Selanjutnya dengan mengacu penelitian terdahulu (Baños-Caballero et al., 2012; Afrifa dan Padachi, 2016; Altaf dan Shah, 2018), dua persamaan berikut diestimasi untuk menguji keberadaan hubungan non linier kuadratik berbentuk $U$ terbalik:

$$
\begin{aligned}
R O E_{i t}= & \alpha_{1}+\beta_{1} N T C_{i t}+\beta_{2} N T C_{i t}^{2}+ \\
& \delta_{1} S I Z E_{i t}+\delta_{2} L E V_{i t}+\delta_{3} C R_{i t}+ \\
& \delta_{4} A T_{i t}+\delta_{5} A G E_{i t}+\varepsilon_{i t} \\
& \\
N P M_{i t}= & \alpha_{1}+\beta_{1} N T C_{i t}+\beta_{2} N T C_{i t}^{2}+ \\
& \delta_{1} S I Z E_{i t}+\delta_{2} L E V_{i t}+\delta_{3} C R_{i t}+ \\
& \delta_{4} A T_{i t}+\delta_{5} A G E_{i t}+\varepsilon_{i t}
\end{aligned}
$$

Untuk menguji apakah pengaruh manajemen modal kerja pada profitabilitas adalah berbeda dalam hal derajat kendala keuangan, persamaan (1) dan (2) lalu diperluas dengan memasukkan variabel dummy DCF ke dalamnya. Prosedur sejenis seperti itu mengikuti Baños-Caballero et al. (2014) dan Afrifa (2016), dan dinyatakan dalam dua persamaan berikut:

$$
\begin{aligned}
R O E_{i t}=\alpha_{1}+ & \beta_{1} N T C_{i t}+\beta_{2} N T C_{i t}^{2} \\
& +\beta_{3} N T C_{i t} \times D C F_{i t} \\
& +\beta_{4} N T C_{i t}^{2} \times D C F_{i t} \\
& +\delta_{1} S I Z E_{i t}+\delta_{2} L E V_{i t} \\
& +\delta_{3} C R_{i t}+\delta_{4} A T_{i t} \\
& +\delta_{5} A G E_{i t}+\varepsilon_{i t} \\
N P M_{i t}=\alpha_{1}+ & \beta_{1} N T C_{i t}+\beta_{2} N T C_{i t}^{2} \\
& +\beta_{3} N T C_{i t} \times D C F_{i t} \\
& +\beta_{4} N T C_{i t}^{2} \times D C F_{i t} \\
& +\delta_{1} S I Z E_{i t}+\delta_{2} L E V_{i t} \\
& +\delta_{3} C R_{i t}+\delta_{4} A T_{i t} \\
& +\delta_{5} A G E_{i t}+\varepsilon_{i t}
\end{aligned}
$$

Seluruh persamaan diestimasi dengan menerapkan model fixed effect dan/atau random effect pada data panel. Asumsiasumsi yang perlu dipertimbangkan di sini ialah mengenai tingginya korelasi antar variabel independen dan korelasi antar errors (Hill et al., 2011). Pengecekan korelasi dilakukan untuk memastikan tidak ada masalah collinearity. Model diestimasi dengan menerapkan cluster-robust standard errors guna mengantisipasi keberadaan heterokedastisitas. Lalu untuk menguji adanya random effects, penelitian ini menerapkan Breusch-Pagan test. Akhirnya dengan mengikuti pernyataan hipotesis penelitian ini dan harapan tandanya, maka persamaan yang diestimasi diharapkan menghasilkan tanda koefisien sebagai berikut: $\beta 1>0, \beta 2<$ $0, \beta 3<0, \beta 4>0, \delta 1 \neq 0, \delta 2 \neq 0, \delta 3 \neq 0, \delta 4 \neq 0$, dan $\delta 5 \neq 0$.

\section{ANALISIS DAN PEMBAHASAN Analisis}

Penelitian ini mengambil sampel perusahaan-perusahaan non keuangan yang masuk dalam industri manufaktur yang terdaftar di Bursa Efek Indonesia. Proses pencarian data pada akhirnya mendapatkan 226 observasi, yang terdiri dari 113 perusahaan selama dua tahun yaitu tahun 2016 dan 2017. Perusahaan dalam sampel mencakup bermacam-macam jenis usaha manufaktur, yaitu: usaha dasar, macam-macam produsen, dan pembuat barang konsumen. 
Statistik deskriptif untuk variabel penelitian ditunjukkan pada Tabel 2. Dua variabel dependen adalah return on equity (ROE) dan net profit margin (NPM). ROE bernilai rata-rata 9,8 persen serta dalam rentang yang cukup menyebar dengan nilai persentil 25 adalah 0,8 persen dan nilai persentil 75 adalah 14,8 persen. Nilai ratarata NPM adalah 1,1 persen pada nilai persentil 25 adalah 0,5 persen dan nilai persentil 75 adalah 8,7 persen. Variabel independen ialah net trade cycle (NTC), yang merupakan ukuran manajemen modal kerja dalam penelitian ini. Nilai rata-rata NTC adalah 102,7 hari, yang mengimplikasikan bahwa perusahaan secara rata-rata perlu sekitar 103 hari untuk mendanai modal kerjanya. Pada NTC, nilai persentil 25 adalah sekitar 53 hari dan nilai persentil 75 adalah 136 hari.

Selain itu, statistik deskriptif untuk kelima variabel kontrol dari penelitian ini juga diperlihatkan pada Tabel 2. Dalam perhitungan logaritma natural, nilai ratarata ukuran perusahaan (SIZE) adalah 22,35. Nilai rata-rata leverage (LEV) adalah 52,8 persen. Current ratio (CR) mempunyai nilai rata-rata adalah 2,13 kali. Dalam hal ini, nilai rata-rata CR ini melebihi "rasio ideal" yang biasanya menunjuk pada 2 kali. Nilai rata-rata asset tangibility (AT) adalah 40,8 persen. Nilai rata-rata usia perusahaan (AGE) adalah 38 tahun. Masing-masing kelima variabel kontrol tersebut terlihat mempunyai rentang nilai persentil 25 dan nilai persentil 75 yang cukup lebar.

Tabel 2

Statistik Deskriptif

\begin{tabular}{lcrrrr}
\hline \hline Variabel & Observasi & Rata-rata & Dev. Standar & p25 & p75 \\
\hline ROE & 226 & 0,098 & 0,33 & 0,008 & 0,148 \\
NPM & 226 & 0,011 & 0,28 & 0,005 & 0,087 \\
NTC & 226 & 102,663 & 92,32 & 53,154 & 136,126 \\
SIZE & 226 & 22,353 & 5,37 & 17,897 & 27,450 \\
LEV & 226 & 0,528 & 0,53 & 0,305 & 0,614 \\
CR & 226 & 2,128 & 1,86 & 1,039 & 2,578 \\
AT & 226 & 0,408 & 0,20 & 0,246 & 0,563 \\
AGE & 226 & 38,075 & 14,48 & 30 & 45 \\
\hline
\end{tabular}

Sumber: data hasil penelitian (diolah)

Karena topik penelitian ini adalah mengenai manajemen modal kerja, maka statistik untuk ukuran NTC menjadi menarik untuk ditelusuri lebih lanjut. Gambar 1 menyajikan nilai rata-rata (mean) dan median dari NTC pada masing-masing ketiga sektor perusahaan yang diteliti. Nampak secara visual, ketiga sektor tersebut mempunyai statistik ringkasan baik nilai rata-rata maupun median yang tidak jauh berbeda satu dengan lainnya yaitu pada sekitar 100an hari. Lebih tepatnya, NTC pada sektor basic industry and chemicals mempunyai rata-rata 98,62 hari dan median 98,38 hari. Sedangkan ukuran NTC pada sektor miscellaneous industry mempunyai rata-rata 98,15 hari dan median 87,77 hari. Selanjutnya NTC pada sektor consumer goods industry mempunyai rata-rata 116,09 hari dan median 91,63 hari. Dengan mencermati statistik ringkasan ini, nilai rata-rata pada masing-masing ketiga sektor tersebut nampak dekat dengan nilai rata-rata NTC keseluruhan perusahaan yaitu 102,7 hari.

Selanjutnya pengamatan dilakukan secara pola tahunan dari NTC. Gambar 2 menyajikan nilai rata-rata dari NTC pada masing-masing ketiga sektor perusahaan yang diteliti dengan membandingkannya antara tahun 2016 dan 2017. 


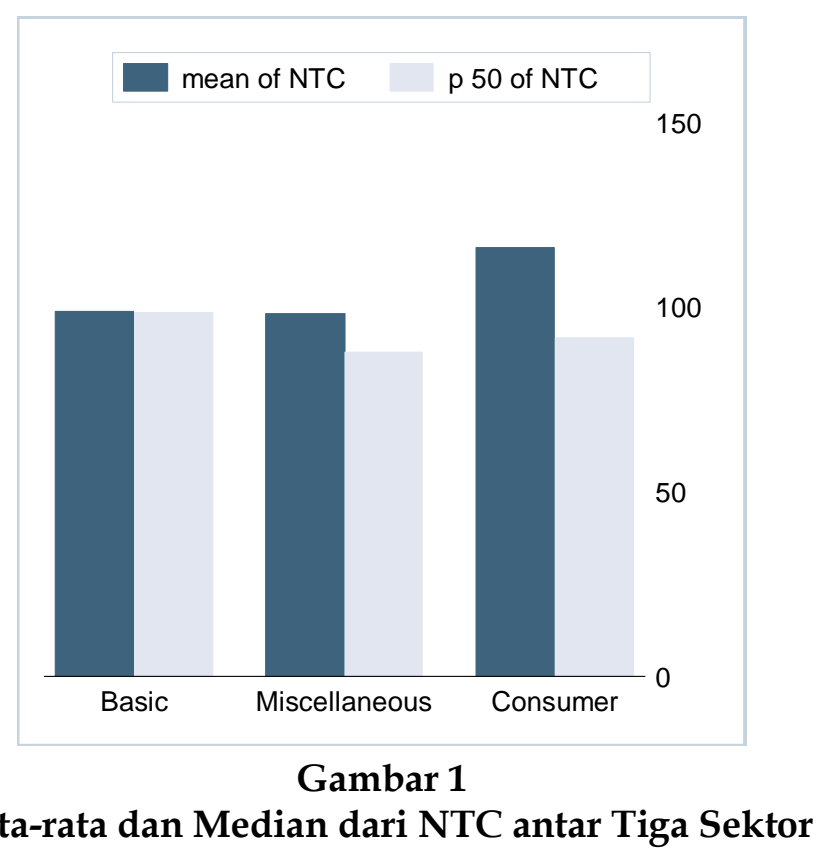

Nampak secara visual, ketiga sektor tersebut mempunyai rata-rata NTC pada tiap kedua tahun tersebut tidak jauh berbeda satu dengan lainnya yaitu pada sekitar 100an hari. Secara lebih rinci, NTC pada sektor basic industry and chemicals mempunyai rata-rata yang sedikit menurun pada tahun 2017 dari tahun 2016. NTC pada sektor miscellaneous industry mempunyai rata-rata yang sedikit menaik pada tahun 2017 dari tahun 2016. Sedangkan NTC pada sektor consumer goods industry mempunyai rata-rata yang hampir tidak berbeda pada tahun 2017 dari tahun 2016.

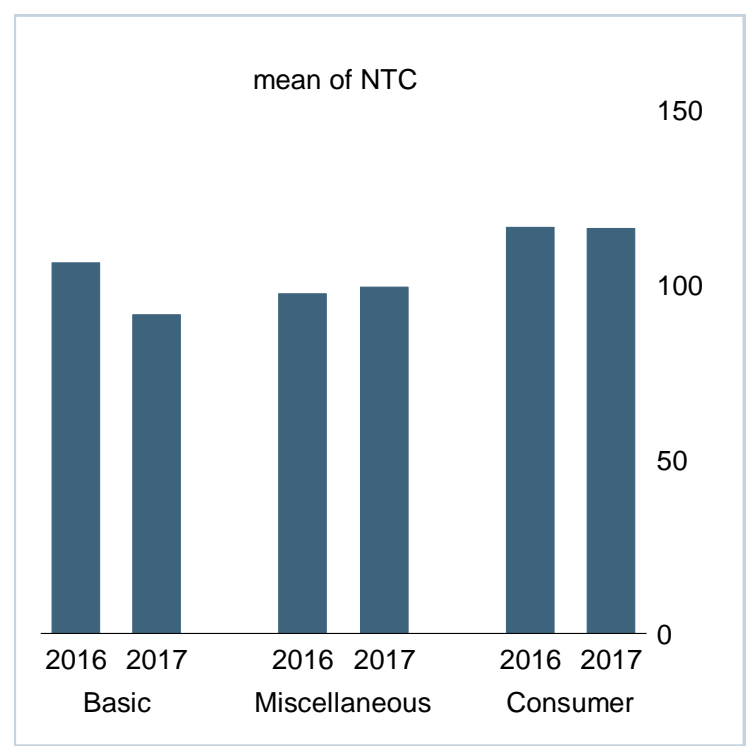

Gambar 2

Rata-rata NTC antar Tiga Sektor pada Tahun 2016 dan 2017

Tabel 3 memperlihatkan satu matriks korelasi antar variabel penelitian. Hasilhasil korelasi menunjukkan tidak adanya hubungan yang signifikan antara ROE dan NPM. Temuan hubungan yang tidak signifikan ini kiranya menjadi menarik pada 
penelitian ini karena keduanya ROE dan NPM merupakan variabel dependen yang digunakan sebagai pengukur profitabilitas perusahaan. Selanjutnya, variabel NTC ditemukan tidak signifikan dalam asosiasi dengan ROE, namun memiliki hubungan positif yaitu 0,40 dan signifikan dengan NPM pada tingkat 1 persen. Hasil-hasil korelasi dari kelima variabel SIZE, LEV, CR, AT, dan AGE memperlihatkan hasil signi fikan yang lebih banyak dengan variabel dependen NPM dibandingkan dengan ROE. Terlihat pada tabel, masing-masing korelasi antar seluruh variabel ditemukan tidak sangat tinggi yang kurang dari 0,5 .

Penelitian ini juga menaruh perhatian terhadap kemungkinan adanya persoalan multikolinearitas. Salah satu prosedur yang efektif untuk mendeteksi keberadaan collinearity adalah dengan mengestimasi apa yang disebut sebagai auxiliary regressions (Hill et al., 2011). Teknisnya, dengan cara saling meregresikan 1 variabel dependen dengan 5 variabel independen dari antara masing-masing 6 variabel NTC, SIZE, LEV, $\mathrm{CR}$, AT, AGE, maka ditemukan $\mathrm{R}^{2}$ dari masing-masing keenam model artifisial ini adalah tidak tinggi, yaitu: 0,$0973 ; 0,0735$; 0,2632; 0.3234; 0,1938; dan 0,1381. Apabila R2 dari model artifisial tersebut adalah tidak tinggi, katakanlah di bawah 0,80, maka collinearity bukanlah merupakan suatu masalah (Hill et al., 2011). Oleh karenanya, collinearity tidak menjadi masalah dalam penelitian ini.

Tabel 3

Matriks Korelasi

\begin{tabular}{llllllll}
\hline \hline & ROE & NPM & NTC & SIZE & LEV & CR & AT \\
\hline ROE & 1,00 & & & & & & \\
NPM & $-0,02$ & 1,00 & & & & & \\
NTC & $-0,10$ & $0,40^{* * *}$ & 1,00 & & & & \\
SIZE & $-0,16^{* *}$ & $-0,02$ & $0,18^{* * *}$ & 1,00 & & & \\
LEV & 0,01 & $-0,21^{* * *}$ & $-0,18^{* * *}$ & $-0,12^{*}$ & 1,00 & & \\
CR & 0,01 & $0,19^{* * *}$ & $0,20^{* * *}$ & $0,15^{* *}$ & $-0,36^{* * *}$ & 1,00 & \\
AT & $-0,10$ & $-0,20^{* * *}$ & $-0,22^{* * *}$ & $-0,22^{* * *}$ & $-0,01$ & $-0,43^{* * *}$ & 1,00 \\
AGE & $0,21^{* * *}$ & $0,11^{*}$ & $-0,06$ & $-0,26^{* * *}$ & $-0,05$ & 0,02 & 0,04 \\
\hline
\end{tabular}

${ }^{*} \mathrm{p}<0,10,{ }^{* *} \mathrm{p}<0,05,{ }^{* * *} \mathrm{p}<0,01$

Sumber: data hasil penelitian (diolah)

Persamaan (1) dan (2) dalam data panel penelitian ini diestimasi menggunakan dua model baik fixed effect maupun random effecs. Hasil-hasilnya ditunjukkan pada Tabel 4 dan Tabel 5. Pengujian Breusch-Pagan test memperlihatkan hasil signifikan menolak hipotesis nol sehingga mengarahkan pada kesimpulan akan keberadaan random effecs (Adkins dan Hill, 2011). Oleh karena itu, persamaan dalam data panel ini diestimasi tidak hanya dengan menggunakan model fixed effect namun juga model random effect. Selain itu, model-model tersebut diestimasi dengan menerapkan cluster-robust standard errors guna mengantisipasi keberadaan heterokedastisitas.

Tabel 4 menunjukkan hasil pengujian regresi panel dengan menggunakan ROE sebagai variabel dependen. Hasil fixed-effects regression memperlihatkan koefisien NTC adalah positif, dan disertai statistik $\mathrm{t}$ sebesar 10,65 yang signifikan pada tingkat 1 persen. Terlebih lagi, koefisien NTC ${ }^{2}$ adalah negatif, dan disertai statistik $t$ sebesar $-5,29$ yang signifikan pada tingkat 1 persen. Sedangkan random-effects regression memperlihatkan 
bahwa koefisien NTC adalah positif, dan disertai statistik $\mathrm{t}=4,35$ yang signifikan pada tingkat 1 persen. Lebih-lebih, koefisien NTC $^{2}$ adalah negatif, dan disertai statistik $\mathrm{t}$ sebesar $-7,45$ yang signifikan pada tingkat 1 persen. Ringkasnya, temuan menunjukkan bahwa koefisien NTC adalah signifikan positif sedangkan koefisien $\mathrm{NTC}^{2}$ adalah signifikan negatif, yang konsisten dengan tanda yang diharapkan. Oleh karena itu, hasil ini mengarahkan dukungan hipotesis penelitian $\mathrm{H}_{1}$ bahwa pengaruh manajemen modal kerja pada profitabilitas (yang diukur dengan ROE) dapat dinyatakan dalam bentuk $U$ terbalik.

Tabel 4

Hasil Pengujian Regresi Panel dengan ROE sebagai Variabel Dependen

\begin{tabular}{lcc}
\hline Variabel dependen: ROE & $\begin{array}{c}\text { Fixed-effects regression } \\
\text { Koef. }(\text { t-stat) }\end{array}$ & $\begin{array}{c}\text { Random-effects regression } \\
\text { Koef. }(z \text {-stat) }\end{array}$ \\
\hline NTC & $0,001535(10,65)^{* * *}$ & $0,000629(4,35)^{* * *}$ \\
NTC & $-1,98 \mathrm{e}-06(-5,29)^{* * *}$ & $-1,99 \mathrm{e}-06(-7,45)^{* * *}$ \\
SIZE & $0,205161(1,02)$ & $-0,009638(-2,53)^{* *}$ \\
LEV & $-1,649081(-3,45)^{* * *}$ & $-0,036812(-0,69)$ \\
CR & $-0,015578(-0,97)$ & $-0,006227(-0,81)$ \\
AT & $-0,788128(-1,01)$ & $-0,259948(-1,25)$ \\
AGE & $-0,042446(-1,17)$ & $0,003638(1,10)$ \\
Constant & $-1,767309(-0,54)$ & $0,286703(1,34)$ \\
\hline N & 226 & 226 \\
F atau Wald chi2 & F $=88,03^{* * *}$ & Wald chi2 $=469,83^{* * *}$ \\
Breusch-Pagan test & & $12,78^{* * *}$ \\
\hline
\end{tabular}

${ }^{*} \mathrm{p}<0,10,{ }^{* *} \mathrm{p}<0,05,{ }^{* * *} \mathrm{p}<0,01$

Sumber: data hasil penelitian (diolah)

Tabel 5 menunjukkan hasil pengujian regresi panel menggunakan NPM sebagai variabel dependen. Hasil fixed-effects regression memperlihatkan bahwa koefisien NTC adalah positif, dan disertai statistik $t$ sebesar 16,19 yang signifikan pada tingkat 1 persen. Terlebih lagi, koefisien NTC ${ }^{2}$ adalah negatif, dan disertai statistik $\mathrm{t}$ sebesar $-17,81$ yang signifikan pada tingkat 1 persen. Sedangkan hasil random-effects regression memperlihatkan bahwa koefisien NTC adalah positif, dan disertai statistik $\mathrm{t}$ sebesar 15,92 yang signifikan pada tingkat 1 persen. Lebihlebih, koefisien $\mathrm{NTC}^{2}$ adalah negatif, dan disertai statistik $t$ sebesar $-18,59$ yang signifikan pada tingkat 1 persen. Dengan demikian, hasil-hasil menunjukkan bahwa koefisien NTC adalah signifikan positif sedangkan koefisien $\mathrm{NTC}^{2}$ adalah signifikan nega tif, yang konsisten dengan tanda yang diharapkan. Oleh karena itu, temuan-temuan penelitian ini mengarahkan kepada dukungan bagi hipotesis penelitian $\mathrm{H}_{1}$ bahwa pengaruh manajemen modal kerja perusahaan terhadap profitabilitas (yang diukur dengan NPM) dapat dinyatakan dalam bentuk $U$ terbalik. Hasil pengujian ini menyepakati temuan sebelumnya pada profitabilitas perusahaan yang diukur dengan ROE. Nilai koefisien dari variabel NTC pada Tabel 4 dan Tabel 5 memungkinkan untuk penentuan titik belok (turning point atau reflecion point) dalam hubungan antara NTC dan profitabilitas perusahaan. Titik belok kurva cekung tersebut dapat dicari dengan menghitung formula $\frac{-\beta_{1}}{2 \beta_{2}}$ dari persamaan 1 dan 2. Formula tersebut diperoleh dengan cara menurunkan (differentiating) variabel profitabilitas terhadap NTC, dan membuat turunannya sama dengan nol (Baños-Caballero et al., 2014). Perhitungan ini diringkas pada Tabel 6. 
Tabel 5

Hasil Pengujian Regresi Panel dengan NPM sebagai Variabel Dependen

\begin{tabular}{lcc}
\hline Variabel dependen: NPM & $\begin{array}{c}\text { Fixed-effects regression } \\
\text { Koef. }(\text { t-stat) }\end{array}$ & $\begin{array}{c}\text { Random-effects regression } \\
\text { Koef. }(z \text {-stat) }\end{array}$ \\
\hline NTC & $0,001332(16,19)^{* * *}$ & $0,001348(15,92)^{* * *}$ \\
NTC 2 & $-2,40 \mathrm{e}-06(-17,81)^{* * *}$ & $-2,98 \mathrm{e}-06(-18,59)^{* * *}$ \\
SIZE & $0,011305(0,29)$ & $-0,004938(-1,58)$ \\
LEV & $-0,016305(-0,13)$ & $-0,056636(-1,12)$ \\
CR & $0,010587(1,38)$ & $0,013950(2,04)^{* *}$ \\
AT & $-0,144688(-1,11)$ & $-0,181886(-1,93)^{*}$ \\
AGE & $-0,019564(-2,18)^{* *}$ & $0,001370(1,02)$ \\
Constant & $0,457112(0,73)$ & $0,061645(0,48)$ \\
\hline N & 226 & 226 \\
F atau Wald chi2 & $\mathrm{F}=1063,32^{* * *}$ & Wald chi2 $=4119,43^{* * *}$ \\
Breusch-Pagan test & \multicolumn{3}{c}{$33,73^{* * *}$} \\
\hline${ }^{*} \mathrm{p}<0,10,{ }^{* *} \mathrm{p}<0,05, * * *$ \\
\hline
\end{tabular}

Sumber: data hasil penelitian (diolah)

Tingkat NTC optimal untuk hasil fixedeffects regression dengan variabel dependen ROE adalah 387,73 hari, untuk hasil randomeffects regression dengan variabel dependen ROE adalah 158,27 hari, untuk hasil fixedeffects regression dengan variabel dependen NPM adalah 277,40 hari, untuk hasil random-effects regression dengan variabel dependen NPM adalah 226,17 hari. Dengan menghitung keseluruhan hasil-hasil ke- empatnya, oleh karenanya tingkat NTC optimal ditemukan antara 158 sampai dengan 387 hari. Apabila dihitung nilai sentral tingkat NTC optimal, maka median adalah 252 hari dan rata-rata adalah 262 hari.

Oleh karena itu, hasil penelitian ini menyampaikan satu taksiran yang bagus untuk tingkat NTC optimal adalah sekitar 255 hari.

Tabel 6

Perhitungan Titik Belok

\begin{tabular}{lcccc}
\hline \hline & ROE, fe & ROE, re & NPM, fe & NPM, re \\
\hline $\mathrm{b}_{1}$ & 0,0015354 & 0,0006299 & 0,0013315 & 0,001348 \\
$\mathrm{~b}_{2}$ & $-1,98 \mathrm{e}-06$ & $-1,99 \mathrm{e}-06$ & $-2,40 \mathrm{e}-06$ & $-2,98 \mathrm{e}-06$ \\
Tingkat NTC optimal & 387,73 & 158,27 & 277,40 & 226,17 \\
\hline Median NTC optimal & \multicolumn{4}{c}{251,79} \\
Rata-rata NTC optimal & \multicolumn{3}{c}{262,39} \\
\hline
\end{tabular}

Sumber: data hasil penelitian (diolah)

Penyelidikan selanjutnya dilakukan untuk menguji pengaruh dari kendala keuangan (financial constraints) terhadap tingkatan modal kerja optimal. Hal ini dilakukan dengan menguji pengaruh kendala keuangan perusahaan dalam hubungan kuadratik antara manajemen modal kerja dan profitabilitas. Seperti telah di- uraikan pada bagian metode penelitian, seluruh perusahaan dibagi menjadi dua menurut arus kas sehingga memberikan satu variabel dummy yang disebut DCF. DCF benilai 1 bagi perusahaan yang lebih terkendala keuangan, dan bernilai 0 untuk perusahaan yang kurang terkendala finansil. Persamaan (1) dan (2) selanjutnya 
diperluas menjadi persamaan (3) dan (4), dan hasil estimasinya diperlihatkan pada Tabel 7 dan Tabel 8. Tabel 7 menyediakan hasil pengujian dari pengaruh kendala keuangan pada hubungan antara NTC dan ROE. Kedua hasil fixed-effects regression dan random-effects regression memperlihatkan tanda koefisien seperti yang diharapkan, yaitu positif untuk NTC dan negatif untuk NTC ${ }^{*}$ DCF serta negatif untuk NTC ${ }^{2}$ dan positif untuk $\mathrm{NTC}^{2 *} \mathrm{DCF}$. Secara lebih rinci terlihat pada hasil menggunakan randomeffects regression, tanda koefisien seperti yang diharapkan, adalah positif untuk NTC (yaitu 0,002306), negatif untuk NTC*DCF (yaitu -,001687), negatif untuk NTC2 (yaitu $7,34 \mathrm{e}-06)$, dan positif untuk $\mathrm{NTC}^{2 *} \mathrm{DCF}$ (5,62e-06). Terlebih lagi, koefisien-koefisien tersebut adalah signifikan berbeda dengan nol pada hasil random-effects regression.

Tabel 7

Pengaruh Kendala Keuangan pada Hubungan antara NTC dan ROE

\begin{tabular}{lcc}
\hline Variabel dependen: ROE & $\begin{array}{c}\text { Fixed-effects regression } \\
\text { Koef. }(\text { t-stat) }\end{array}$ & $\begin{array}{c}\text { Random-effects regression } \\
\text { Koef. }(z \text {-stat) }\end{array}$ \\
\hline NTC & $0,002056(2,14)^{* *}$ & $0,002306(3,74)^{* * *}$ \\
NTC ${ }^{*}$ & $-2,76 \mathrm{e}-06(-0,68)$ & $-7,34 \mathrm{e}-06(-3,79)^{* * *}$ \\
NTC ${ }^{*}$ DCF & $-0,000512(-0,56)$ &,$- 001687(-3,29)^{* * *}$ \\
NTC2*DCF & $7,67 \mathrm{e}-07(0,20)$ & $5,62 \mathrm{e}-06(2,64)^{* * *}$ \\
SIZE & $0,207011(1,03)$ & $-0,009386(-2,57)^{* *}$ \\
LEV & $-1,598709(-3,04)^{* * *}$ & $-0,019241(-0,37)$ \\
CR & $-0,015364(-0,99)$ & $-0,012080(-1,45)$ \\
AT & $-0,7^{*} 67658(-0,97)$ & $-0,233425(-1,15)$ \\
AGE & $-0,040150(-1,05)$ & $0,003454(1,05)$ \\
Constant & $-1,951091(-0,61)$ & $0,234502(1,12)$ \\
\hline N & 226 & 226 \\
F atau Wald chi2 & $\mathrm{F}=81,37^{* * *}$ & Wald chi2 $=427,64^{* * *}$ \\
Breusch-Pagan test & \multicolumn{2}{c}{$11,13^{* * *}$} \\
\hline${ }^{*} \mathrm{p}<0,10,{ }^{* *} \mathrm{p}<0,05,{ }^{* * *} \mathrm{p}<0,01$ & & \\
Sumber: data hasil penelitian (diolah) & &
\end{tabular}

Hasil-hasil sejenis juga diperlihatkan untuk variabel dependen NPM pada Tabel 8. Baik fixed-effects regression dan randomeffects regression juga memperlihatkan tanda koefisien seperti diharapkan, yaitu positif untuk NTC dan negatif untuk NTC*DCF serta negatif untuk $\mathrm{NTC}^{2}$ dan positif untuk $\mathrm{NTC}^{2 *}$ DCF. Secara lebih rinci terlihat pada hasil menggunakan random-effects regression, tanda koefisien seperti yang diharapkan, adalah positif untuk NTC (yaitu 0,002459), negatif untuk NTC*DCF (yaitu -0,001093), negatif untuk $\mathrm{NTC}^{2}$ (yaitu -6,52e-06), dan positif untuk NTC ${ }^{2 *}$ DCF $(3,63 \mathrm{e}-06)$. Terlebih lagi, koefisien-koefisien tersebut signifikan berbeda dengan nol pada hasil randomeffects regression. Oleh karena itu, hasil-hasil ini dan juga pada Tabel 7 mendukung hipotesis penelitian $\mathrm{H}_{2}$ bahwa kendala keuangan berpengaruh pada hubungan kuadratik antara manajemen modal kerja dan profitabilitas.

\section{Pembahasan}

Penelitian ini menaruh perhatian pada manajemen modal kerja perusahaan dengan menghitung net trade cycle (NTC). Hasil menunjukkan bahwa nilai rata-rata NTC adalah 102,7 hari, yang mengimplikasikan bahwa perusahaan secara rata-rata memerlukan sekitar 103 hari untuk mendanai modal kerjanya. Studi Shin dan Soenen (1998) menemukan bahwa rata-rata NTC adalah sekitar 90 hari pada perusahaan 
Amerika. Baños-Caballero et al. (2012) menemukan rata-rata NTC adalah 56 hari pada perusahaan non keuangan di Inggris. Satu kecurigaan ialah bahwa lebih tingginya NTC pada perusahaan Indonesia dikarenakan berada di negara dan pasar modal yang sedang berkembang.
Akan tetapi pada perusahaan non keuangan yang terdaftar di bursa saham Spanyol, Baños-Caballero et al. (2013) memperlihatkan bahwa rata-rata (median) NTC adalah 115,19 $(91,46)$ hari, dan median NTC untuk sektor manufaktur adalah 100,35 hari.

Tabel 8

Pengaruh Kendala Keuangan pada Hubungan antara NTC dan NPM

\begin{tabular}{lcc}
\hline Variabel dependen: NPM & $\begin{array}{c}\text { Fixed-effects regression } \\
\text { Koef. }(\text { t-stat) }\end{array}$ & $\begin{array}{c}\text { Random-effects regression } \\
\text { Koef. }(\boldsymbol{z} \text {-stat) }\end{array}$ \\
\hline NTC & $0,002237(3,61)^{* * *}$ & $0,002459(5,29)^{* * *}$ \\
NTC & $-5,08 \mathrm{e}-06(-2,32)^{* *}$ & $-6,52 \mathrm{e}-06(-4,40)^{* * *}$ \\
NTC*DCF & $-0,000885(-1,59)$ & $-0,001093(-2,72)^{* * *}$ \\
NTC2*DCF & $2,66 \mathrm{e}-06(1,19)$ & $3,63 \mathrm{e}-06(2,32)^{* *}$ \\
SIZE & $0,012138(0,32)$ & $-0,004724(-1,54)$ \\
LEV & $0,051336(0,38)$ & $-0,040671(-0,87)$ \\
CR & $0,010345(1,49)$ & $0,010961(1,76)^{*}$ \\
AT & $-0,116181(-0,91)$ & $-0,162669(-1,80)^{*}$ \\
AGE & $-0,015804(-1,86)^{*}$ & $0,001283(0,95)$ \\
Constant & $0,222816(0,37)$ & $0,019321(0,15)$ \\
\hline N & 226 & 226 \\
F atau Wald chi2 & F $=978,13^{* * *}$ & Wald chi2 $=4,623,80^{* * *}$ \\
Breusch-Pagan test & \multicolumn{2}{c}{$36,08^{* * *}$} \\
\hline
\end{tabular}

${ }^{*} \mathrm{p}<0,10,{ }^{* *} \mathrm{p}<0,05,{ }^{* * *} \mathrm{p}<0,01$

Sumber: data hasil penelitian (diolah)

Hasil-hasil analisis regresi data panel memperlihatkan temuan yang menyepakati bagi hubungan kuadratik berbentuk $U$ terbalik antara manajemen modal kerja (NTC) dan profitabilitas (keduanya baik ROE maupun NPM) pada perusahaan manufaktur terbuka Indonesia. Hasil-hasil penelitian ini menyarankan bahwa peningkatan modal kerja akan meningkatkan profitabilitas ketika tingkat modal kerja adalah rendah, namun profitabilitas akan menurun dengan peningkatan modal kerja ketika tingkat modal kerja adalah tinggi. Temuan ini menyediakan satu dukungan empiris bagi studi-studi terdahulu (BañosCaballero et al., 2012; Afrifa dan Padachi, 2016; Altaf dan Shah, 2018). Tambahan lagi, faktor kendala keuangan mempunyai pengaruh pada hubungan antara modal kerja dan profitabilitas perusahaan. Hasil pe- nelitian ini mengkonfirmasi temuan-temuan sejenis sebelumnya dari studi pada perusahaan di negara maju (Baños-Caballero $e t$ al., 2014; Afrifa, 2016).

Hasil-hasil penelitian sekarang ini mengindikasikan bahwa perusahaan mempunyai tingkat modal kerja optimal yang karenanya akan memaksimalkan profitabilitas. Tingkat NTC yang optimal ditemukan adalah antara 158 hari sampai dengan 387 hari. Rentang tersebut bisa jadi diinterpretasikan terlalu lebar bagi pembaca kritis. Sehubungan dengan cukup lebarnya rentang tersebut, penelitian ini mungkin mengandung satu kelemahan dalam hal kekurangmampuan pada menghitung NTC optimal yang kiranya akan lebih baik apabila cukup stabil akan hasil-hasil persamaan estimasinya. Meski begitu, jika dihitung nilai sentral tingkat dari NTC optimal, maka 
median adalah 252 hari dan rata-rata adalah 262 hari. Atas dasar pertimbangan ini, maka satu taksiran yang bagus bagi tingkat NTC optimal adalah sekitar 255 hari.

Diskusi ini selanjutnya bisa lebih dipertajam lagi. Statistik perusahaan dalam sampel sebelumnya telah memperlihatkan nilai rata-rata dan median dari NTC adalah sekitar 100an hari. Sementara taksiran bagi tingkat NTC optimal adalah sekitar 255 hari. Oleh karena itu, lebih banyak perusahaan dalam sampel penelitian ini yang mestinya berada dalam posisi yang lebih baik dalam profitabilitas dengan adanya peningkatan investasi dalam modal kerja daripada mengusahakan penurunan tingkat modal kerja perusahaan.

\section{SIMPULAN DAN SARAN}

Tidak hanya keputusan jangka panjang, manajemen keuangan perusahaan juga menaruh perhatian pada bagaimana manajer mengelola kegiatan hariannya yang berhubungan dengan keputusan keuangan jangka pendek. Manajemen modal kerja menunjuk pada hal-hal yang terkait dengan aktiva lancar seperti piutang usaha dan persediaan serta terkait dengan kewajiban lancar seperti hutang usaha. Dalam hal ini, manajer perusahaan perlu mengelola modal kerja dengan sebaik-baiknya agar kinerja perusahaan yang tinggi dapat terpelihara.

Hasil penelitian ini menyampaikan simpulan bahwa hubungan antara manajemen modal kerja dan profitabilitas pada perusahaan manufaktur terbuka Indonesia bisa dinyatakan dalam hubungan kuadratik yang berbentuk pola $U$ terbalik. Peningkatan investasi modal kerja akan meningkatkan profitabilitas perusahaan ketika tingkat modal kerja adalah rendah, namun profitabilitas akan menjadi menurun ketika tingkat modal kerja adalah terlalu tinggi.

Hasil-hasil penelitian ini menyediakan manfaat kepada manajer perusahaan dalam pengelolaan modal kerjanya. Perubahan dalam ukuran manajemen modal kerja bisa jadi menjadi penanda yang tepat bagi monitoring kesehatan perusahaan. Adanya perubahan dalam ukuran manajemen modal kerja, yang menjadi semakin terlalu panjang ataukah sebaliknya menjadi terlalu pendek, seharusnya dicurigai kemungkinan adanya persoalan yang terkait dengan penanganan piutang usaha, persediaan, dan hutang usaha. Hasil-hasil penelitian ini menyarankan agar manajer perusahaan mencari suatu tingkat investasi modal kerja optimal bagi perusahaannya agar mencapai kinerja profitabilitas yang maksimal.

Berdasarkan pengamatan terhadap statistik deskriptif dari NTC, terlihat secara pola tren tahunan NTC mengalami sedikit perbedaan pada tahun 2017 dibandingkan dengan tahun 2016. Temuan ini kiranya dapat menyediakan petunjuk awal yang bagus bagi penelitian mendatang untuk mengeksplorasi pola runtut waktu tahun-ke tahun dalam periode waktu yang lebih lama dari investasi modal kerja perusahaan manufaktur. Macam penelitian seperti ini akan menyampaikan manfaat bagi literatur manajemen modal kerja maupun manajer perusahaan Indonesia.

\section{DAFTAR PUSTAKA}

Adkins, L. C. dan R. C. Hill. 2011. Using Stata for Principles of Econometrics. 4th ed. John Wiley \& Sons, Inc.

Afrifa, G. A. 2016. Net Working Capital, Cash Flow and Performance of UK SMEs. Review of Accounting and Finance 15(1): 21-44.

Afrifa, G. A. dan K. Padachi. 2016. Working Capital Level Influence on SME Profitability. Journal of Small Business and Enterprise Development 23(1): 44-63.

Altaf, N. dan F. A. Shah. 2018. How Does Working Capital Management Affect the Profitability of India Companies?. Journal of Advances in Management Research 15(3): 347-366.

Baños-Caballero, S., P. J. García-Teruel, dan P. Martínez-Solano. 2012. How Does Working Capital Management Affect the Profitability of Spanish SMEs?. Small Business Economics 39(2): 517-529. 
Baños-Caballero, S., P. J. García-Teruel, dan P. Martínez-Solano. 2013. The Speed of Adjustment in Working Capital Requirement. European Journal of Finance 19(10): 978-992.

Baños-Caballero, S., P. J. García-Teruel, dan P. Martínez-Solano. 2014. Working Capital Management, Corporate Performance, and Financial Constraints. Journal of Business Research 67(3): 332338.

CNN Indonesia. 2017. OJK: 69 Persen Dana dari Lantai Bursa untuk Modal Kerja. https://www.cnnindonesia.com/ekonomi/20 170412184625-92-207110/ojk-69-persendana-dari-lantai-bursa-untuk-modal-kerja. Diakses tanggal 24 January 2019.

Deloof, M. 2003. Does Working Capital Management Affect Profitability of Belgian Firms?. Journal of Business Finance and Accounting 30(3): 573-87.

Dewi, L. dan Y. Rahayu. 2016. Pengaruh Perputaran Modal Kerja terhadap Profitabilitas Perusahaan Manufaktur di Bursa Efek Indonesia. Jurnal Ilmu dan Riset Akuntansi 5(1): 1-17.

Fazzari, S.M. dan B. Petersen. 1993. Working Capital and Fixed Investment: New Evidence on Financing Constraints. Rand Journal of Economics 24: 328-342.

Gitman, L. J. dan C. J. Zutter. 2012. Principles of Managerial Finance. 13th ed. Prentice Hall, Inc.

Hill, R. C., W. E. Griffiths, dan G. C. Lim. 2011. Principles of Econometrics. 4th ed. John Wiley \& Sons, Inc.

Kirui, B. K. dan N. H. W. Wawire. 2018. Measures of Financial Constraints in Kenya. International Journal of Economics and Financial Issues 8(1): 217-231.

Li, D. 2011. Financial Constraints, R \& D Investment, and Stock Returns. Review of Financial Studies 24(9): 2974-3007.

Lyngstadaas, H. dan T. Berg. 2016. Working Capital Management: Evidence from Norway. International Journal of Managerial Finance 12(3): 295-313.

Meidiyustiani, R. 2016. Pengaruh Modal Kerja, Ukuran Perusahaan, Pertumbu- han Penjualan dan Likuiditas terhadap Profitabilitas pada Perusahaan Manufaktur Sektor Industri Barang Konsumsi yang Terdaftar di Bursa Efek Indonesia (BEI) Periode Tahun 2010-2014. Jurnal Akuntansi dan Keuangan 5(2): 161-179.

Nobanee, H., M. Abdullatif, dan M. AlHajjar. 2011. Cash Conversion Cycle and Firm's Performance of Japanese Firms. Asian Review of Accounting 19(2): 147-156.

Pais M.A. dan P.M. Gama. 2015. Working Capital Management and SMEs Profitability: Portuguese Evidence. International Journal of Managerial Finance 11(3): 341-358.

Preve, L. A. dan V. Sarria-Allende. 2010. Working Capital Management. Oxford University Press, Inc.

PwC. 2015. Bridging the Gap. Annual Global Working Capital Survey. 1-49.

Reimeinda, V., S. Murni, dan I. Saerang. 2016. Analisis Pengaruh Modal Kerja terhadap Profitabilitas pada Industri Telekomunikasi di Indonesia. Jurnal Berkala Ilmiah Efisiensi 16(3): 207-218.

Ross, S. A., R. W. Westerfield, dan B. D. Jordan. 2013. Fundamentals of Corporate Finance. 10th ed. McGraw-Hill Companies, Inc.

Shin, H.H. dan L. Soenen. 1998. Efficiency of Working Capital and Corporate Profitability. Financial Practice and Education 8(2): 37-45.

Singhania, M. dan Mehta, P. 2017. Working Capital Management and Firms' Profitability: Evidence from Emerging Asian Countries. South Asian Journal of Business Studies 6(1): 80-97.

Utami, M. S. dan M. R. Dewi S. 2016. Pengaruh Manajemen Modal Kerja terhadap Profitabilitas Perusahaan Manufaktur yang Terdaftar di Bursa Efek Indonesia. E-Jurnal Manajemen Unud 5(6): 3476-3503.

Veli, A. 2015. The Effect of Cash Conversion Cycle on Profitability of Small and Medium Sized Enterprises. International 
Journal of Management Sciences and Business Research 4(2): 66-72.

Wasiuzzaman, S. 2015. Working Capital and Firm Value in an Emerging Market. International Journal of Managerial Finance 11(1): 60-79.

Wiyono, G. 2017. Efektifitas Manajemen Siklus Konversi Kas Perusahaan Sektor Aneka Usaha Terdaftar di BEI. Ekuitas: Jurnal Ekonomi dan Keuangan 1(4): 451471.
Yazdanfar, D. dan P. Ohman. 2014. The Impact of Cash Conversion Cycle of Firm Profitability: an Empirical Study Based on Swedish Data. International Journal of Managerial Finance 10(4): 442452.

Zakari, M. dan S. Saidu. 2016. The Impact of Cash Conversion Cycle on Firm Profitability: Evidence from Nigerian Listed Telecommunication Companies. Journal of Finance and Accounting 4(6): 342-350. 